\title{
Matija MATIĆ: The Croatian-Slavonian Diet and its Legislative Activity during World War I
}

\author{
University of Zagreb, Faculty of Law
}

DOI 10.21862/siaa.5.3

\section{Introduction}

World War I acted as a catalyst for various political processes that received new directions throughout the war. In such a chaos of different political ideas, the Diets of the Old World Order were counting down their last days of legislative activity. Some Diets, such as the Dalmatian, Istrian or Bosnian Diet, did not experience the onset of the First World War at all. Their legislative activities were suspended. ${ }^{1}$ On the other hand, the Croatian-Slavonian Diet and the Diet of Hungary continued their work, largely thanks to the Prime Minister of the Hungarian Central Government István Tisza, who advocated maintaining of the constitutional and political stability in the Hungarian, Transleithanian part of the Monarchy, and thanks to the Croatian Ban Ivan Skerlecz for Croatia.

In the first part of the paper, we elaborate the position of the Croatian-Slavonian Diet within the Austro-Hungarian Monarchy, its functions and its structure, the legislative process, and other characteristics. In the second part, we present the legislative activity through two phases. The first phase consists of quantitative analysis, which will help to understand the dynamics of legislative activity from the beginning of the war to its end. In the second phase, we present a qualitative analysis by which we show what kind of matter the Diet was regulating at the time. The separate laws will

\footnotetext{
1 ČEPULO, Dalibor: Hrvatska pravna povijest u europskom kontekstu [Croatian Legal History in the European Context]. Zagreb, 2021, Pravni fakultet Sveučilišta u Zagrebu, p. 207.
} 
serve as an example of what the Diet thought was the most important to regulate during the World War I. The third part of the paper is about the end of the CroatianSlavonian Diet and its dissolution.

\section{Croatian-Slavonian Diet}

\subsection{Croatian-Slavonian Diet state affairs}

The Hungarian-Croatian Compromise of 1868 established two categories of state affairs. On the one hand, there were autonomous powers of Croatia and on the other were joint powers with Hungary. Joint powers were enumerated in the Compromise itself, while autonomous powers were the rest. The autonomous powers consisted of four segments. The systematization of these powers portrayed three different Croatian Land Government departments. These departments were as follows: Department for Internal Administration, Department for Education and Religion, and Department of Justice. ${ }^{2}$

In addition, the Diet was autonomous in adopting the land budget, but only when approved the expenditures made by the Croatian Land Government. ${ }^{3}$ Diet also had the authority in passing its own rules of procedure. It was also able to elect a president and vice-president. MPs had the right of legislative proposal, and they had a right of parliamentary immunity. The Croatian-Slavonian Diet elected twenty-nine deputies to the House of Representatives and two members to the House of Magnates of the Hungarian-Croatian Diet. In the Hungarian-Croatian Diet, the delegates of Croatia-Slavonia were allowed to use Croatian in the proceedings, but they voted personally. ${ }^{4}$

\footnotetext{
${ }^{2}$ Ibid., p. 179.

${ }^{3}$ SIROTKOVIĆ, Hodimir: Organizacija Sabora Hrvatske i Slavonije u nagodbenom razdoblju (1868-1918). Arhivski vjesnik. 34-35 (1991-1992), 35-36, p. 28.

${ }^{4}$ ČEPULO, op. cit., pp. 181-183.
} 


\subsection{The legislative process}

The legislative process was very complicated. Croatian-Slavonian Diet worked in plenary sessions and committees, and the legislative process itself was comprised of three readings. In the first reading, the basic principles of the proposal were discussed and voted on. In the second reading, each amendment to individual articles of the bill was discussed and voted on, while in the third reading, the entire draft law was voted on without discussion. When the statute was approved by the Diet, it was sent by the Ban to the ruler for royal assent through the Croatian-Slavonian Minister in the Central Government in Budapest. After ruler's agreement, the laws were subjected to the Croatian-Slavonian Minister and the Croatian Ban on their countersignatures, after which they were published in the Croatian Code of Laws. ${ }^{5}$ Such a rather extensive and complicated process enabled the Hungarian Central Government to more easily control the legislative activity of the Diet itself.

\subsection{Structure of the Diet and the electoral law}

The Diet was a unicameral chamber parliament with a dual structure made up of MPs and virilists. ${ }^{6}$ The number of MPs was fixed at 90 in 1888, previously higher due to the annexation of the Croatian Military Frontier in 1881 (112). ${ }^{7}$ The number of virilists was limited to half the number of MPs, which was up to 45. Two of the seats the law provided for Rijeka representatives, but due to the unresolved disputes of the status of Rijeka, those seats were never filled. Electoral law limited suffrage significantly. Only after the reforms of 1910 voting right was expanded to $8 \%$, and such a census remained

\footnotetext{
${ }^{5}$ lbid., p. 183.

6 Ibid.

${ }^{7}$ SiRotKović, op. cit., p. 23.
} 
during the World War I. Efforts had been made to give all adult men the right to vote, but it never came into effect. ${ }^{8}$

\subsection{Croatian-Slavonian Diet other characteristics}

The king summoned and dissolved the Diet through the Ban. The authorities extended duration of the convocation in 1888 from the traditional three to five years to harmonize with equal extension of the Hungarian Diet. ${ }^{9}$ Significance of interpellations was marginalized. The political responsibility of the Ban was not foreseen because the appropriate institutional mechanisms did not exist. The legal responsibility of the Ban, introduced in 1874 , was too complicated.

An important right of the Diet that was often used was the traditional right of giving the address to the king. The Croatian-Slavonian Diet often used this power to inform the ruler about the urgent problems of Croatia and to request the resolution of certain constitutional problems of the country's affairs. The address was the only constitutional means of maintaining contacts between the ruler and the representative body of Croatia, so it is not surprising that it was used quite often in Croatia's constitutional practice. ${ }^{10}$ Based on all said, one can conclude that the Diet was a legislative body for the country's autonomous affairs and a traditional symbol of Croatian autonomy, but it was not a real parliament. ${ }^{11}$

\section{The World War I and the Croatian-Slavonian Diet - the context}

\footnotetext{
${ }^{8}$ ČEPULO, op. cit., p. 183.

${ }^{9}$ GosZTONYI, Gergely: Erdély és a társországok [Transylvania and the partner countries]. In: MEZEY, Barna - GosztonyI, Gergely (eds.): Magyar alkotmánytörténet [Hungarian constitutional history]. Budapest, 2020, Osiris Kiadó, p. 125.

10 ČEPULO, op. cit., p. 183-184.

${ }^{11}$ SIROTKOVIĆ, op. cit., p. 22.
} 
As already mentioned, World War I orchestrated various number of different political processes and goals parties wanted to achieve. In Croatia, the main political processes that resonated at that time was the question of national position of the state and its peoples after the end of the war. There were three possible outcomes. The Croatia would either maintain itself and become a part of a third entity comprised of Slavic peoples inside a reorganized Austro-Hungarian Monarchy, or it would be unified with the rest of the South Slavic peoples with the leading role of Serbia, or a large portion of its territories would be incorporated into a Greater Serbian state. ${ }^{12}$

Thus, the political climate took place in which numerous agreements were concluded based on one of the mentioned possible outcomes. During the war, there was never a clear and one political goal that all the parties agreed on and wanted to achieve. There was never a consensus. The majority in the Diet belonged to the CroatSerb Coalition, whose political manifesto included various political, social, and economic reforms, equality and co-operation between Croats and Serbs, recognition of the Croatian-Hungarian Settlement and co-operation with Hungarian parties against the imposition of Austrian centralist interests. In addition to the coalition itself, various fractions of the Croatian Party of Rights (Starćević, Pure) also operated in the Diet, Radić HPPS (Croatian Peasant Party) also operated, and a smaller number of MPs were Unionists. $^{13}$

\section{Quantitative and qualitative analysis of the legislative activity during the War}

\subsection{Quantitative analysis of the scope of legislative activity in the Diet}

Regarding the quantitative analysis of the scope of work in the Diet, the figures are as follows: from 1914 to 1918, the Croatian-Slavonian Diet passed 68 laws. In 1914 it

\footnotetext{
12 ČEPULO, op. cit., p. 207.

${ }^{13}$ ĐUKIĆ, Filip - PAVELIĆ, Marko - ŠAUR, Silvijo: Hrvatska u Prvom Svjetskom ratu - Bojišta, stradanja, društvo [Croatia in World War I - Battlefields, suffering, society]. Essehist. 2015, vol. 7., no. 7., pp. 83.
} 
passed 20, in 1915 5, in 1916 12, in 1917 10, and in $191821 .{ }^{14}$ To understand the dynamics of law-making, it is necessary to know the context of the political situation of each of the mentioned years.

\subsection{Qualitative analysis of the scope of legislative activity in the Diet}

In 1914, most of the laws were passed before the beginning of the war, but the readiness of the Diet to pass laws on the content of war can be seen at the very beginning of the war. One of them is the Law on the Supply of Land Employees in the Kingdoms of Croatia and Slavonia, Their Widows and Orphans. The law regulates who is entitled to any allowance or pension, which conditions must be met, how much they can get at least, and how much the most, and when the given privilege eventually ends. ${ }^{15}$ As already indicated, due to the circumstances of the war, the number of passed laws from this year began to decline.

As for 1915, the Law on Property Liabilities for Treasonous Offenses Committed during the War should be singled out. ${ }^{16}$ The law regulates the relations of a soldier caught in the act of high treason and regulates the trial that should be held against him. In 1916, one of the most important laws passed was the Law on the Recognition of the Islamic Religion, which was necessary after the annexation of Bosnia and Herzegovina in $1908 .{ }^{17}$ The law passed marriage rules for Muslims, but also declared the mandatory application of marriage rules of the Austrian Civil Code, thus preventing polygamy. It was one of the first laws on the equality of Islam in Europe - similar laws in Europe were previously passed in Spain, Austria and Hungary. ${ }^{18}$

Huge war devastations and casualties marked the year 1918. In Croatia, historically speaking, it was a period of an enormous humanitarian crisis over the

\footnotetext{
${ }^{14}$ https://alex.onb.ac.at/cgi-content/alex-iv.pl [Access on January 10, 2022].

15 Law on the Supply of Land Employees in the Kingdoms of Croatia and Slavonia, Their Widows and Orphans, 1914.

${ }^{16}$ Law on Property Liabilities for Treasonous Offenses Committed during the War, 1915.

${ }^{17}$ Law on the Recognition of the Islamic Religion, 1916.

${ }^{18}$ ČEPULO, op. cit., p. 207.
} 
problem of providing shelter to an explicit number of Bosnian and Serbian child refugees (more than 20 000) affected by the devastations of war. In those circumstances, Croatian social activists, led by Đuro Basariček, showed exceptional readiness to provide shelter to war victims, regardless of their nationality or religion. ${ }^{19}$ That's why the Diet devoted most of its time to legislative activity dedicated to those most affected by the war. In line with this, the Diet enacted the Law on Children's Homes and the Law on the Legalization of Children if the Father died or was pronounced dead. ${ }^{20}$ In addition, the Diet enacted The Law on the Proclamation of Dead. This law regulated primarily the issue of death of a soldier, and stated that a soldier will be declared dead if disappeared two years ago and if there were not any news that he is alive. ${ }^{21}$

Finally, on October 29 of 1918 the Diet unanimously declared the dissolution of all state relations: "between the Kingdom of Croatia, Slavonia and Dalmatia on the one hand, and the Kingdom of Hungary and the Kingdom of Austria on the other."

\section{Conclusion}

In understanding the work and structure of today's Croatia Parliament, it is necessary to know its history. The Croatian-Slavonian Diet not only stands out for its historical and legal importance in knowing today's institutions of the Croatian legislature, but it is most importantly a symbol of Croatia's autonomy and the overall Croatia's identity.

World War I answers the question of what the Diet was able to regulate at that time. It also answered the question of what were the main priorities of the Diet in a state of war. The number of laws is not comparable in quantity to, for example, the

\footnotetext{
${ }^{19}$ ĐUKIĆ - PAVELIĆ - ŠAUR, op. cit., p. 84.

${ }^{20}$ Law on Children's Homes, 1918; Law on the Legalization of Children if the Father died or was pronounced dead, 1918.

${ }^{21}$ Law on the Proclamation of the Dead, 1918.
} 
number of laws passed by the Hungarian Diet or any other Parliament at that time, but its continued work is an excellent indicator of Croatia's readiness to react and pass laws even in the times of chaotic, catastrophic conducts of war. ${ }^{22}$

22 ČEPULO, op. cit., p. 261-262. 